\title{
Antibody dynamics and spontaneous viral clearance in patients with acute hepatitis C infection in Rio de Janeiro, Brazil
}

\author{
Alexander M Strasak ${ }^{1 \dagger}$, Arthur Y Kim ${ }^{2 \dagger}$, Georg M Lauer ${ }^{3}$, Paulo S de Sousa ${ }^{4}$, Cleber F Ginuino ${ }^{4}$, \\ Carlos A Fernandes ${ }^{5}$, Carlos E Velloso ${ }^{4}$, Adilson J de Almeida ${ }^{4,6}$, Jaqueline M de Oliveira ${ }^{7}$, Clara F Yoshida ${ }^{4}$, \\ Julian Schulze zur Wiesch ${ }^{8}$, Gláucia Paranhos-Baccalá ${ }^{9}$, Stefan Lang ${ }^{10}$, Larry J Brant ${ }^{11}$, Hanno Ulmer ${ }^{1}$, \\ Susanne Strohmaier', Lalit Kaltenbach', Elisabeth Lampe ${ }^{4}$, Lia L Lewis-Ximenez ${ }^{4^{*}}$
}

\begin{abstract}
Background: The anti-HCV antibody response has not been well characterized during the early phase of HCV infection and little is known about its relationship to the clinical course during this period.

Methods: We analyzed serial anti-HCV antibodies longitudinally obtained from a prospective cohort of 65 patients with acute HCV infection by using a microparticle enzyme immunoassay AxSYM HCV 3.0 (Abbott Diagnostics) during the first 12 months from HCV acquisition in Rio de Janeiro, Brazil. Spontaneous viral clearance (SVC) was defined as undetectable HCV RNA in serum, in the absence of treatment, for three consecutive HCV PCR tests within 12-months of follow-up.

Results: Baseline antibody values were similar among patient groups with self-limiting HCV evolution $(n=34)$ and persistent viremia $(n=31)$ [median (interquartile range) signal/cut-off ratio $(\mathrm{s} / \mathrm{co}) 78.7$ (60.7-93.8) vs. 93.9 (67.8111.9), $p=0.26]$. During 12-months follow-up, patients with acute spontaneous resolving HCV infection showed significantly lower serial antibody response in comparison to individuals progressing to chronic infection [median (interquartile range) s/co 62.7 (35.2-85.0) vs. 98.4 (70.4-127.4), p < 0.0001]. In addition, patients with self-limiting HCV evolution exhibited an expeditious, sharp decline of serial antibody values after SVC in comparison to those measured before SVC [median (interquartile range) s/co 56.0 (25.4-79.3) vs. 79.4 (66.3-103.0), p < 0.0001].
\end{abstract}

Conclusion: Our findings indicate a rapid short-term decline of antibody values in patients with acute spontaneous resolving HCV infection.

\section{Background}

Acute hepatitis $\mathrm{C}$ virus (HCV) infection accounts for approximately $20 \%$ of cases of acute hepatitis today, with an estimated 30,000 to 40,000 new cases occurring every year in the United States alone. Worldwide at least 170 million individuals are chronically infected with HCV [1-4]. The natural history of HCV infection is heterogeneous and incorporates a range of prognostic determinants [1-6]. Untreated, acute HCV infection

\footnotetext{
* Correspondence: lialewis.fiocruz@gmail.com

† Contributed equally

${ }^{4}$ Viral Hepatitis Laboratory, Oswaldo Cruz Institute, FIOCRUZ, Rio de Janeiro, Brazil

Full list of author information is available at the end of the article
}

progresses to chronic infection in $50-80 \%$ of patients [7-9]. Rates of spontaneous HCV resolution (SVC) reported from prospective studies substantially vary, with estimates ranging from 10 to $60 \%[2-6,10,11]$.

As acute HCV infection is clinically inapparent in most cases, longitudinal data on the natural course of early disease remain sparse [12] with the immunologic correlates of spontaneous recovery being poorly understood [13]. While antibodies detected by commercially available tests, have been widely used for diagnosing $\mathrm{HCV}$ infection, there is little information on the timing, magnitude, specificity and clinical relevance of the antibody dynamics during acute HCV infection, and its relation to short-term disease outcome widely remains 
unclear [1,2,14-19]. We here present detailed 12-month follow-up data on serial antibody values in a Brazilian cohort of 65 patients with acute HCV infection, followed prospectively from the initial phase, between 2001 and 2009. We compared longitudinal patterns of antibody ratios between individuals with self-limiting acute $\mathrm{HCV}$ evolution and patients progressing to chronic infection.

\section{Methods}

We have recently published the results of an acute $\mathrm{HCV}$ cohort in Rio de Janeiro, Brazil [20], which showed an independent relationship of peak anti-HCV antibody levels and disease outcome. However, in this study we extended the study prospectively to 12 months and used serial anti-HCV antibody ratios obtained from a commercial microparticle enzyme immunoassay (MEIA) AxSYM HCV 3.0 (Abbott Laboratories) and serial qualitative HCV RNA detected by the Cobas Amplicor Monitor HCV test (Roche Diagnostics) for analysis. Patients who did not clear HCV RNA during early follow-up were referred for antiviral therapy. Six of the patients in the present study underwent antiviral treatment within the first 12 months from infection and their anti-HCV antibody ratios were not considered for analysis during and after the treatment period. A more detailed description of the program methodology and study cohort has been reported previously [20].

This study was approved by the Research on Human Subjects Ethics Committee of the Oswaldo Cruz Foundation as well as the Brazilian National Research Ethics Commission. Signed informed consent was obtained from all participants.

\section{Laboratory Methods}

Following diagnosis of acute HCV infection, samples were obtained from study participants at approximately every two weeks for the first, second and third month and then monthly from the fourth month to one year between 2001 to 2009 . Overall $85 \%$ of scheduled blood draws were obtained. Serum samples obtained serially were aliquoted for serological and molecular testing and stored at $-80^{\circ} \mathrm{C}$. Samples were thawed only once for laboratory testing. Repeat tests were performed for anti-HCV antibody testing or HCV RNA detection on separate samples obtained at the same time point. Anti-HCV antibody testing results were obtained from ratios between sample absorbance and the calculated cut-off for each sample (s/co) with the automated MEIA AXSYM HCV 3.0. The qualitative determination of HCV RNA was carried out by the Cobas Amplicor Monitor HCV test (Roche Diagnostics) which has a detection limit of $50 \mathrm{IU} / \mathrm{ml}$. First time samples that were $\mathrm{HCV}$ RNA undetectable by the Cobas Amplicor Monitor were retrospectively reevaluated by the VERSANT HCV RNA
Qualitative Assay (TMA) (Siemens Healthcare Diagnostics) with a lower detection limit of $9.6 \mathrm{IU} / \mathrm{ml}$.

\section{Definitions}

Diagnosis of acute HCV infection was based upon previously established criteria [10,11,21]: (1) a positive antiHCV antibody or HCV RNA result in a patient with a negative anti-HCV test result within the past year, or (2) a positive anti-HCV and HCV RNA result in a patient with clinical hepatitis, ALT levels 10 times the upper limit of normal (32 U/L); or, (3) in absence of detectable HCV RNA, history of high-risk exposure between 1 and 3 months prior to clinical manifestation in anti-HCV seropositive patients. Further details on the diagnosis of acute HCV infection is described elsewhere [20]. To estimate the date of $\mathrm{HCV}$ infection the day of high-risk exposure was used, or, when unavailable, as either 6 weeks before the onset of symptoms in symptomatic patients $[7,10]$, or 6 weeks before seroconversion in asymptomatic patients [10,15].

Spontaneous viral clearance (SVC) was defined as undetectable HCV RNA in serum within the first 12 months of follow-up after the estimated date of infection, in the absence of treatment. Since oscillations in HCV RNA detection are frequently observed in the early phase of HCV infection, two additional consecutive negative HCV RNA test results were required to sustain SVC classification [22,23]. The midpoint between the date of the first of three consecutive RNA-negative samples and the date of the last positive HCV RNA was used as the estimated date of SVC. For six patients with undetectable HCV RNA in the first sample collected, the date of SVC was estimated as the midpoint between the date of infection and the date of the first undetectable HCV RNA sample [10,11].

\section{Statistical Analysis}

Inter-individual differences in baseline antibody values (i.e. measurements at first visit) and median antibody values during prospective 12-months follow-up between patients with self-limiting and chronic HCV evolution were assessed using independent samples t-test. Serial patterns of longitudinal antibody values between patient groups were analyzed by means of linear mixed-effects regression models, utilizing intra-individual differences and multiple measurements per patient over time. Twosided p-values $<0.05$ were considered statistically significant. All analyses were performed using STATA 10.0 and SAS 9.1 statistical software.

\section{Results}

\section{Patient characteristics}

40 women $(61.5 \%)$ and 25 men $(38.5 \%)$ comprised the cohort eligible for analysis. Mean age at HCV infection 
was 45.7 years (range, 20-77 years). 54/65 patients (83.1\%) experienced disease symptoms (including jaundice and/or dark urine) during follow-up. During the 12-month follow-up 439 serial antibody measurements were obtained (median per patient 6.0, range 1-16). Antibody values were approximately normally distributed, with a sample absorbance/cut-off ratio (s/co) ranging from 0.4 to 185.6. After 12 months of follow-up, $34 / 65$ patients $(52.3 \%)$ had spontaneously recovered from acute $\mathrm{HCV}$, including 5 with clearance after six months of follow-up. A detailed comparison of sociodemographic and clinical characteristics between individuals with acute spontaneous resolving HCV infection and patients' progression to chronic infection has been previously reported by our group [20].

\section{Longitudinal Antibody Response and Spontaneous HCV Clearance}

Baseline antibody ratios were similar among patient groups with self-limiting HCV evolution $(\mathrm{n}=34)$ and persistent viremia $(\mathrm{n}=31)$ [median (interquartile range IQR) s/co ratio 78.7 (60.7-93.8) vs. 93.9 (67.8-111.9), $\mathrm{p}=$ 0.26 , Table 1]. Compared to patients with persistent viremia, patients with self-limiting HCV evolution had significantly lower median and serial antibody ratios $[105.5 \mathrm{~s} / \mathrm{co}$ (IQR 75.4-123.6) vs. 66.2 s/co (IQR 47.8-79.5), p < 0.0001, and 98.4 s/co (IQR 70.4-127.4) vs. $62.7 \mathrm{~s} / \mathrm{co}$ (IQR 35.285.0), $\mathrm{p}<0.0001$, Table 1]. In addition, patients with selflimiting $\mathrm{HCV}$ infection showed a significant and sharp decline of serial antibody ratios after SVC [79.4 s/co (IQR 66.3-103.0) before SVC vs. 56.0 s/co (IQR 25.4-79.3) after SVC, $\mathrm{p}<0.0001$, Table 1].

\section{Discussion}

We present the antibody dynamics during the initial phase of disease in 65 individuals with acute HCV infection, prospectively followed in Rio de Janeiro, Brazil. Although different profiles of long-term humoral immune response between spontaneous clearers and chronic carriers have previously been described in $\mathrm{HCV}$ infection [13,17-19,24,25], the dynamics of humoral responses during the acute phase of infection are less well documented due to the fact that acute $\mathrm{HCV}$ cohorts and prospective data from the early phase of disease are rare [12]. Our previous study had demonstrated that low levels of anti-HCV are predictive of spontaneous viral clearance in the acute phase of infection in patients followed during a 6-month period. This study, however, in extending the study to a 12-month time period, identified an additional 5 cases of SVC and shows that longitudinal antibody response may be used as a predictor of spontaneous viral during early phase of $\mathrm{HCV}$ infection when rapid declines in anti-HCV antibodies occur. From a clinical standpoint, two or more serial values may be more feasible than examining peak antibody values [20] as a discriminator of outcome.

Takaki and colleagues [13] analyzed the HCV-specific humoral immune responses in patients infected with HCV over an 18-20 year course of infection after documented exposure and found that a large number of patients with viral clearance tested negative for antiHCV antibodies. Messick and colleagues [24] studied a cohort of haemophiliacs exposed to HCV infection and observed significant decrease in anti-HCV antibody ratios in patients with viral clearance when compared to those with persistent viremia over a period of 15 years. $\mathrm{Lu}$ and co-workers [25], described persistently low antibody s/co ratios in subjects with spontaneous viral resolution, suggesting that antibody ratios might not rise significantly in those who spontaneously recover.

It has been speculated that the partial or total loss of anti-HCV antibodies in immunocompetent patients that have spontaneously recovered from HCV may be attributed to the lack of HCV antigen that would sustain antibody levels $[24,26]$. Studies in chimpanzees have already shown that low doses of $\mathrm{HCV}$ inoculum may promote cellular immune responses in chimpanzees but rarely produce detectable viremia or seroconversion [27]. Cross-sectional studies have additionally demonstrated that indeterminate and weak antibody reactivity are each

Table 1 Anti-HCV antibodies (s/co) during first 12 months of follow-up in 65 patients with acute HCV infection, stratified according to viral clearing status, Rio de Janeiro, Brazil, 2001-2009 ${ }^{\mathrm{a}}$

\begin{tabular}{|c|c|c|c|c|c|c|}
\hline \multirow[t]{2}{*}{ Anti-HCV Antibodies (s/co) } & \multicolumn{3}{|c|}{$\operatorname{SVC}^{b}(\mathrm{n}=34)$} & \multirow[t]{2}{*}{ Non-SVC $(n=31)$} & \multirow{2}{*}{$\begin{array}{l}\text { p-value SVC vs. } \\
\text { Non-SVC }\end{array}$} & \multirow{2}{*}{$\begin{array}{l}\text { p-value before } \\
\text { SVC vs. after SVC }\end{array}$} \\
\hline & Total & Before SVC & After SVC & & & \\
\hline At Baseline/First Visit & $78.7(60.7-93.8)$ & n.a. ${ }^{c}$ & n.a. & $93.9(67.8-111.9)$ & 0.26 & n.a. \\
\hline Median during follow-up & $66.2(47.8-79.5)$ & $71.0(55.8-80.0)$ & $55.1(17.9-71.8)$ & $105.5(75.4-123.6)$ & $<0.0001$ & 0.04 \\
\hline Serial during follow-up ${ }^{d}$ & $62.7(35.2-85.0)$ & $79.4(66.3-103.0)$ & $56.0(25.4-79.3)$ & $98.4(70.4-127.4)$ & $<0.0001$ & $<0.0001$ \\
\hline
\end{tabular}

${ }^{a}$ Data given as median (interquartile range).

b Spontaneous Viral Clearance (SVC) was defined as a series of at least 3 negative HCV RNA results within 12 months after the estimated point of infection.

c n.a. denotes not applicable.

d All anti-HCV antibody measures per patient during the first 12 months from the estimated date of infection were considered and weighted equally.

P-value for group comparison calculated from linear-mixed effects regression. 
important predictors of absence of HCV viremia [28]. Our data provide additional information regarding the timing of emergence of this antibody pattern, showing that the $\mathrm{HCV}$-specific humoral immune response declines early after clearance, once antigenic stimulus is removed.

Our study does have potential limitations that should be considered. First, patients in our cohort were predominantly symptomatic and of female sex, with both characteristics previously being shown to be associated with favourable outcome in acute HCV infection [6]. Second, exact date of exposure was not available for all patients and had to be estimated on the basis of established criteria. However, sensitivity analyses previously conducted by our group [20] indicated that the impact of this limitation is negligible. Finally, sample size eligible for the present analyses was relatively small and time periods between prospective follow-up visits and numbers of serial antibody measures varied among study participants, preventing us from evaluating antibody responses at uniform time points for all patients during follow-up.

\section{Conclusions}

Our data indicate a rapid short-term decline of antibody values in patients with acute spontaneous resolving $\mathrm{HCV}$ infection, with the dynamics of this decline being significantly faster than previously appreciated. These findings suggest that $\mathrm{HCV}$ antibody testing performed years after infection might be less reliable than currently thought as a marker for HCV exposure, with underestimation of the rate of $\mathrm{HCV}$ infection and spontaneous clearance. Serial anti-HCV antibody ratio measurements may also distinguish outcome and could be useful for prognosis in settings where HCV RNA testing is unavailable or constrained by resource limitations.

\section{Acknowledgements \\ Our research was supported by National Institute of Health (NIH) grant Al066345-05, and CGLAB/Ministry of Health, Brazil.}

\section{List of abbreviations}

HCV: hepatitis C virus; SVC: spontaneous viral clearance; ALT: alanine aminotransferase; $\mathrm{s} / \mathrm{co}$ : sample absorbance to cut-off ratio

\section{Conflicts of interest}

All authors: no conflicts

\section{Individual Authors 'contributions}

AMS, AYK, GML, JSZW, GPB, EL, LLL: Conception and design of study PSF, CFG, CAF, CEV, AJA, JMO, CFTY, LK, EL, LLL: Acquisition of data and data management

AMS, SL, LB, HU SS, LK, LLL: Statistical analysis and interpretation of data AMS, AYK, GML, JSZW, SS, LLL: Drafting of manuscript

AMS, AYK, GML AJA, JSzW, HU, SS, LLL: Critical revising of manuscript for important intellectual content

All authors read and approved the final manuscript.

\section{Author details}

'Department of Medical Statistics, Informatics and Health Economics, Innsbruck Medical University, Innsbruck, Austria. ${ }^{2}$ Division of Infectious Diseases, Massachusetts General Hospital and Harvard Medical School, Boston, USA. ${ }^{3}$ Gastrointestinal Unit, Massachusetts General Hospital and Harvard Medical School, Boston, USA. ${ }^{4}$ Viral Hepatitis Laboratory, Oswaldo Cruz Institute, FIOCRUZ, Rio de Janeiro, Brazil. ${ }^{5}$ Hepatitis Division, Central Public Health Laboratory Noel Nutels, Rio de Janeiro, Brazil. ${ }^{6}$ Hematology Unit, Gaffrée \& Guinle University Hospital, Federal University of the State of Rio de Janeiro, Rio de Janeiro, Brazil. 'Viral Technology Laboratory, Oswaldo Cruz Institute, FIOCRUZ, Rio de Janeiro, Brazil. ${ }^{8}$ Medizinische Klinik I, Universitätsklinikum Eppendorf, Hamburg, Germany. ${ }^{9}$ Emerging Pathogens Laboratory, Fondation Merieux, Lyon, France. ${ }^{10}$ Institute of Statistics, University of Innsbruck, Innsbruck, Austria. ${ }^{11}$ Gerontology Research Center, National Institute on Aging, Baltimore, USA.

Received: 22 July 2010 Accepted: 12 January 2011

Published: 12 January 2011

\section{References}

1. Gerlach JT, Diepolder HM, Zachoval R, Gruener NH, Jung MC Ulsenheimer A, Schraut WW, Schirren CA, Waechtler M, Backmund M, Pape GR: Acute hepatitis C: high rate of both spontaneous and treatment-induced viral clearance. Gastroenterology 2003, 125:80-88.

2. Corey KE, Ross AS, Wurcel A, Schulze Zur Wiesch J, Kim AY, Lauer GM, Chung RT: Outcomes and treatment of acute hepatitis $C$ virus infection in a United States population. Clin Gastroenterol Hepatol 2006, 4:1278-1282.

3. The Global Burden of Hepatitis C Working Group: Global burden of disease (GBD) for hepatitis C. J Clin Pharmacol 2004, 44:20-29.

4. Maheshwari A, Ray S, Thuluvath PJ: Acute hepatitis C. Lancet 2008, 372:321-332

5. Thomas DL, Seeff LB: Natural history of hepatitis C. Clin Liver Dis 2005, 9:383-398

6. Micallef JM, Kaldor JM, Dore GJ: Spontaneous viral clearance following acute hepatitis $C$ infection: A systematic review of longitudinal studies. J Viral Hepat 2006, 13:34-41.

7. Hofer H, Watkins-Riedel T, Janata O, Penner E, Holzmann H, SteindlMunda P, Gangl A, Ferenci P: Spontaneous viral clearance in patients with acute hepatitis $\mathrm{C}$ can be predicted by repeated measurements of serum viral load. Hepatology 2003, 37:60-64.

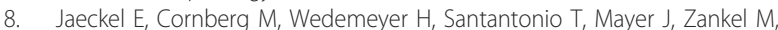
Pastore G, Dietrich M, Trautwein C, Manns MP, German Acute Hepatitis C Therapy Group: Treatment of acute hepatitis $\mathrm{C}$ with interferon alfa-2b. N Engl I Med 2001, 345:1452-1457.

9. Blackard JT, Shata MT, Shire NJ, Sherman KE: Acute hepatitis C virus infection: a chronic problem. Hepatology 2008, 47:321-331.

10. Wang CC, Krantz E, Klarquist J, Krows M, McBride L, Scott EP, Shaw-Stiffel T, Weston SJ, Thiede H, Wald A, Rosen HR: Acute hepatitis C in a contemporary US cohort: Modes of acquisition and factors influencing viral clearance. J Infect Dis 2007, 196:1474-1482.

11. Sharaf Eldin N, Ismail S, Mansour H, Rekacewicz C, El-Houssinie M, ElKafrawy S, El Aidi S, Abdel-Hamid M, Esmat G, Pol S, Fontanet A, Mohamed MK: Symptomatic acute hepatitis C in Egypt: diagnosis, spontaneous viral clearance, and delayed treatment with 12 weeks of pegylated interferon alfa-2a. PLoS One 2008, 3(12):e4085.

12. Cox AL, Page K, Bruneau J, Shoukry NH, Lauer GM, Kim AY, Rosen HR, Radziewicz H, Grakoui A, Fierer DS, Branch AD, Kaplan DE, Chang KM: Rare birds in North America: acute hepatitis C cohorts. Gastroenterology 2009, 136:26-31.

13. Takaki A, Wiese M, Maertens G, Depla E, Seifert U, Liebetrau A, Miller JL, Manns MP, Rehermann B: Cellular immune responses persist and humoral responses decrease two decades after recovery from a single-source outbreak of hepatitis C. Nat Med 2000, 6:578-582.

14. Orland JR, Wright TL, Cooper S: Acute hepatitis C. Hepatology 2001 33:321-327.

15. Netski DM, Mosbruger T, Depla E, Maertens G, Ray SC, Hamilton RG, Roundtree S, Thomas DL, McKeating J, Cox A: Humoral immune response in acute hepatitis C virus infection. Clin Infect Dis 2005, 41:667-675. 
16. Chen M, Sällberg M, Sönnerborg A, Weiland O, Mattsson L, Jin L, Birkett A Peterson D, Milich DR: Limited humoral immunity in hepatitis $C$ virus infection. Gastroenterology 1999, 116:135-143.

17. Heller T, Rehermann B: Acute hepatitis C: a multifaceted disease. Semin Liver Dis 2005, 25:7-17.

18. Logvinoff C, Major ME, Oldach D, Heyward S, Talal A, Balfe P, Feinstone SM, Alter $\mathrm{H}$, Rice CM, McKeating JA: Neutralizing antibody response during acute and chronic hepatitis C virus infection. Proc Natl Acad Sci USA 2004, 101:10149-10154.

19. Nikolaeva LI, Blokhina NP, Tsurikova NN, Voronkova NV, Miminoshvili MI, Braginsky DM, Yastrebova ON, Booynitskaya OB, Isaeva OV, Michailov MI, Archakov Al: Virus-specific antibody titers in different phases of hepatitis C virus infection. J Viral Hepat 2002, 9:429-437.

20. Lewis-Ximenez LL, Lauer GM, Schulze Zur Wiesch J, de Sousa PS, Ginuino CF, Paranhos-Baccalá G, Ulmer H, Pfeiffer KP, Goebel G, Pereira JL, Mendes de Oliveira J, Yoshida CF, Lampe E, Velloso CE, Alves Pinto M, Coelho HS, Almeida AJ, Fernandes CA, Kim AY, Strasak AM: Prospective Follow-Up of Patients with Acute Hepatitis C Virus Infection in Brazil. Clin Infect Dis 2010, 50:1222-1230.

21. Amin J, Law MG, Micallef J, Jauncey M, Van Beek I, Kaldor JM, Dore GJ: Potential biases in estimates of hepatitis C RNA clearance in newly acquired hepatitis $C$ infection among a cohort of injecting drug users. Epidemiol Infect 2007, 135:144-150.

22. Cox AL, Netski DM, Mosbruger T, Sherman SG, Strathdee S, Ompad D, Vlahov D, Chien D, Shyamala V, Ray SC, Thomas DL: Prospective evaluation of community-acquired acute-phase hepatitis $\mathrm{C}$ virus infection. Clin Infect Dis 2005, 40:951-958.

23. McGovern BH, Birch CE, Bowen MJ, Reyor LL, Nagami EH, Chung RT, Kim AY: Improving the diagnosis of acute hepatitis $C$ virus infection with expanded viral load criteria. Clin Infect Dis 2009, 49:1051-1060.

24. Messick K, Sanders JC, Goedert JJ, Eyster ME: Hepatitis C viral clearance and antibody reactivity patterns in persons with haemophilia and other congenital bleeding disorders. Haemophilia 2001, 7:568-574.

25. Lu SN, Tung HD, Chen TM, Lee CM, Wang JH, Hung CH, Chen $\mathrm{CH}$, Changchien CS: Is it possible to diagnose acute hepatitis C virus (HCV) infection by a rising anti-HCV titre rather than by seroconversion? I Viral Hepat 2004, 11:563-570.

26. Lefrère $\mathrm{JJ}$, Guiramand $\mathrm{S}$, Lefrère $\mathrm{F}$, Mariotti $\mathrm{M}$, Aumont $\mathrm{P}$, Lerable J, Petit JC, Girot $R$, Morand-Joubert L: Full or partial seroreversion in patients infected by hepatitis C virus. J Infect Dis 1997, 175:316-322.

27. Shata MT, Tricoche N, Perkus M, Tom D, Brotman B, McCormack P, Pfahler W, Lee DH, Tobler LH, Busch M, Prince AM: Exposure to low infective doses of HCV induces cellular immune responses without consistently detectable viremia or seroconversion in chimpanzees. Virology 2003, 314:601-616.

28. Bossi V, Galli C: Quantitative signal of anti-HCV by an automated assay predicts viremia in a population at high prevalence of hepatitis $C$ virus infection. J Clin Virol 2004, 30:45-49.

\section{Pre-publication history}

The pre-publication history for this paper can be accessed here: http://www.biomedcentral.com/1471-2334/11/15/prepub

\section{doi:10.1186/1471-2334-11-15}

Cite this article as: Strasak et al: Antibody dynamics and spontaneous viral clearance in patients with acute hepatitis C infection in Rio de Janeiro, Brazil. BMC Infectious Diseases 2011 11:15.

\section{Submit your next manuscript to BioMed Central and take full advantage of:}

- Convenient online submission

- Thorough peer review

- No space constraints or color figure charges

- Immediate publication on acceptance

- Inclusion in PubMed, CAS, Scopus and Google Scholar

- Research which is freely available for redistribution 